\title{
Kaukasus: Mellem stjernestøv og ragnarok Benedicte Maegaard
}

\section{Afbalanceret skildring der i kort form giver over- blik over en kompleks og kompliceret region}

Ib Faurby: Det politiske spil om Kaukasus. Forsvarets oplysnings- og velfardstjeneste, København 2006, 126 s.

Ib Faurby kan sit Kaukasus og netop derfor er det så imponerende, at det er lykkedes for ham at give en så komprimeret og objektiv beskrivelse af området, som han gør i denne lille perle af en bog på 126 smalle sider. Bogen er meget pædagogisk sat op med gode kort, den giver et glimrende overblik og samtidig svar på alle de spørgsmål, man kan stille om denne komplicerede og fascinerende region.

Kaukasus er en bjergkæde med nogle af verdens (næst)højeste bjerge, som strækker sig fra Sortehavet til Det Kaspiske Hav. På nordsiden af bjergene ligger syv etnisk definerede, delvist selvstyrende republikker i Den Russiske Føderation, hvoraf den kendteste er Tjetjenien. Sydkaukasus består af Armenien, Aserbajdsjan og Georgien. Kaukasus er det etnisk mest sammensatte område i Europa; der er mellem 40 og 50 forskellige folkeslag med hver sin kultur og eget sprog. Området har været beboet siden stenalderen. Styreformerne er præget af klanvælde.

Faurby fremhæver, at i Kaukasus finder man stort set alle de problemer, der har præget verden efter afslutningen af den Kolde Krig. Der har været krige og borgerkrige med uhyrlige krigsforbrydelser; der har været etnisk udrensning og flygtningekatastrofer; der er mafiaøkonomi og terrorisme; og der har været stormagtsrivalisering om politisk indflydelse og kontrol over olierigdomme. Det har vist sig vanskeligt at gennemføre reformer for at skabe demokrati og markedsøkonomi. Ingen af landene har haft demokratiske traditioner at vende tilbage til eller bygge på. Gennemførelse af økonomiske reformer kræver en fundamental omstilling fra den sovjetiske planøkonomi og opgør med den ud- 
bredte korruption og mafiaøkonomi.

Regionen er generelt præget af fattigdom og stor arbejdsløshed. I Tjetjenien er den skyhøj - hvilket får særligt alvorlige konsekvenser for de unge. Modsat oplever Aserbajdsjan sit andet olieboom, som tiltrækker kapital, der fx bygger 340 højhuse i Baku (det er flere end på Manhattan). Men ude i landet uden for Baku, hvor olien findes (omkring byen og i Det Kaspiske Hav) ser man ikke meget til rigdommen. Da Det Kaspiske Hav jo er et indhav, er der bygget rørledninger til at føre olien og gassen væk - og de fører ikke den korteste vej (gennem Armenien) - eller sammen med de tidligere rørledninger gennem Rusland ud til Sortehavet, men gennem Georgien og NATO-landet Tyrkiet ud til Middelhavet. Dette hænger sammen med de komplicerede sikkerhedspolitiske realiteter i Kaukasus.

Armenien har sin velhavende diaspora i Vesten, der sender så mange penge hjem, at de udgør halvdelen af BNI. Aserbajdsjans og Georgiens diaspora består derimod af unge, fattige arbejdsføre mænd, der i milliontal rejser til Rusland for at udføre især sæsonarbejde - og sælge produkterne fra de frugtbare dele af landene på markederne i Rusland. Hvis de ikke rejste bort, kunne det store landbrugspotentiale i det frodige lavland syd for bjergene udnyttes langt bedre.

Kaukasus er også præget af flygtninge og fordrevne fra områdets konflikter. Særligt i Georgien og Aserbajdsjan er der fortsat store problemer omkring disse grupper, hvoraf mange lever under kummerlige forhold. Dertil kommer mindretalsproblemer (bla. armenere og azeriere i Georgien).

Kaukasus er blevet en region, hvor stormagter og nabolande konkurrerer om politisk og økonomisk indflydelse - både sikkerhedspolitisk og i forhold til olieforekomsterne på bunden af Det Kaspiske Hav. Og landene konkurrerer selv om stormagternes gunst - Georgien (og Aserbajdsjan) bejler til Vesten og om USA's gunst. Da præsident Bush besøgte Georgien, blev alle huse langs hans rute malet i flotte farver, hvilket giver mindelser om Potemkins kulisser. Forholdet til Rusland er Georgiens helt dominerende udenrigspolitiske problem. Aserbajdsjan har et problematisk forhold til tre af sine fire nabolande: Rusland, Armenien og Iran (bla. pga. olien, men også pga. Nagornyi-Karabakh-enklaven). Armenien er Ruslands eneste allierede i regionen og får sine grænser bevogtet af russisk grænsepoliti. Armenien er stadig ikke på talefod med Tyrkiet efter massakrerne i 1915.

\section{Hvorfor konflikter og krige}

Der er en række låste konflikter i Kaukasus: i Tjetjenien, i Georgien omkring Syd-Ossetien (på sydsiden af Kaukasusbjergene) og Abkhasien ved Sortehavet (begge med stærke 


\section{LITTERATUR}

russiske interesser), og omkring Nagornyi-Karabakh mellem Aserbajdsjan og Armenien. Der er ikke officielle forbindelser mellem de to lande - og der er mange tragedier forbundet med konflikten. Jeg har fx oplevet en hjerteskærende genforening af fire generationer af en familie, der var blevet spredt over de to lande og ikke havde set hinanden i 16 år pga. konflikten - mødet, der fandt sted på neutral grund, kunne desværre kun blive kort.

Det undrer én, når man oplever de smukke lande og møder varmen og gæstfriheden fra beboerne, at området er så præget af konflikter og krige. Faurby gør en rosværdig indsats for at give mosaikker til forklaring af det komplicerede billede: Dels er der tale om ældgamle etniske modsætninger (som blev holdt nede af den kommunistiske undertrykkelse, men igen er kommet op til overfladen). Omvendt finder han også historisk mange eksempler på fordragelig sameksistens.

Den kommunistiske undertrykkelse skabte i høj grad modsætninger mellem folkeslagene i Sovjetunionen - del og hersk politikken over for de ikke-russiske folkeslag indebar bl.a. indretning af nogle uhensigtsmæssige administrative grænser. Og med Sovjetunionens opløsning blev flere af disse tidligere administrative grænser i Kaukasus til internationale grænser. Dermed blev flere folkeslag, der hidtil havde levet $\mathrm{i}$ samme stat, splittet - det gælder fx osseterne, der nu bor i hhv. Rusland og Georgien, og armenerne i Nagornyi-Karabakh.

Endvidere medvirkede den nationale mobilisering, der fandt sted i de nye stater, til, at de etniske mindretal frygtede for, at de ville blive marginaliseret eller direkte undertrykt. Det gælder bl.a. en række af mindretallene i Georgien, herunder de armenske og azeriske i de sydlige dele af landet.

Hvad har fået konflikterne til at blusse op ? Det er der iflg. Faurby en række forklaringer på:

- Konflikterne har rod i tidligere overgreb (fx deportationerne i 1944 af tjetjenerne, de meskhetiske tyrkere m.fl.).

- Sovjetunionens censur og direkte historieforfalskning skabte grobund for nationalistiske myter.

- Skrupelløse personer forsøger at skabe sig en politisk karriere som nationalistiske ledere ved at appellere til historiske myter.

- Selvom etniske modsætninger ikke er den egentlige konfliktårsag, kan en konflikt skabe eller forstærke sådanne. Dette gælder bl.a. russiske overgreb på civilbefolkningen i Tjetjenien, gensidige etniske udrensninger mellem armenere og azeriere, fordrivelsen af georgiere fra Abkhasien, der har forstærket etniske modsætninger og skærpet konflikterne. - Og helt uanset en konflikts oprindelige årsag, så vil krigshandlinger næsten altid forstærke modsætningsforhold mellem parterne. Krigen får 
dermed sin egen ødelæggende logik. Dertil kommer, at de mange flygtninge ofte bidrager til at holde konflikterne ved lige dels pga. de $ø$ konomiske problemer, de skaber, dels ved at de modsætter sig kompromisser, der kunne løse konflikten. - Nogen søger forklaringen på konflikterne i Kaukasus i religiøse modsætninger mellem muslimer og ortodokse kristne. Det afviser Faurby dog, idet han fx påpeger, at Nagornyi-Karabakh-konflikten mellem det kristne Armenien og det muslimske Aserbajdsjan er en strid om territorium og ikke om religion. Det samme gælder Abkhasien. Tjetjenien-konflikten har bevirket fremvækst af religiøs fundamentalisme - ikke omvendt, som Rusland har hævdet. - Økonomiske modsætninger og alvorlige økonomiske kriser i Kaukasus har øget konfliktpotentialet. Og når først en konflikt er brudt ud, kan der være grupper, der tjener på den og derfor ønsker, den skal fortsætte. Krig kan også benyttes til legitimering af handlinger, der ellers ville blive betragtet som kriminelle. - Selv om borgerkrige normalt betragtes som 'interne konflikter' så er de - specielt i svage stater - aldrig fuldstændig interne. Der er sammenhæng mellem flere af konflikterne i Kaukasus. - Udenlandsk indblanding har i flere tilfælde forstærket konflikter eller hindret deres løsning. Dette gælder først og fremmest Rusland. Den russisk-tjetjenske konflikt har lange hi- storiske rødder, og centralmagten i Moskva ønsker fortsat at få politisk styr på de ikke-russiske folkeslag $\mathrm{i}$ Nordkaukasus. Som nævnt spiller Rusland stadig en stor rolle også i Sydkaukasus, bl.a. med sin støtte til Abkhasiens faktiske løsrivelse fra Georgien. Mht. Nagornyi-Karabach mener mange, at russisk politik har haft til formål at kontrollere konflikten uden at løse den.

Faurby ønsker for Kaukasus, at det internationale engagement må øges for at bidrage til at stabilisere den sikkerhedspolitiske situation. Især hvis de internationale organisationer gør deres støtte betinget af fredelig bilæggelse og konfliktløsning. (Omvendt kan man befrygte, at øget international opmærksomhed fører til skærpet konkurrence og større spænding). Fra dansk side har man bl.a. støttet et grænseoverskridende netværk af NGO'er, der især beskæftiger sig med flygtninge og fordrevne - og med løsninger på konflikterne. Vi giver også støtte til løsninger på mindretalsproblemerne.

\section{Stjernestøv og ragnarok}

Faurby har på imponerende vis givet en afbalanceret og kortfattet skildring af hele den komplekse region. Han har dygtigt manøvreret mellem skærene - og det er svært at se, at ret mange af spillerne i Kaukasus ville kunne blive særligt fornærmede over hans fremlæggelse af problemstillingerne. 


\section{LITTERATUR}

Når man holder sig så sikkert på objektivitetens smalle vej, savner læseren lidt duften af det fascinerende Kaukasus - de spændende historier, myterne, rygterne, beskyldningerne, rænkerne, modsætningerne, forsoningen, smilene. Paradislandet, som er så fascinerende, men også trættende.

Vil man have stjernestøv, må man kaste sig over litteraturen - eller rejse til Kaukasus, hvor man ud over stjernestøv dog også møder ragnarok. Ud over høje hvide bjerge og grønne, frugtbare dale møder man kulde, regn, stegende hede, elendige veje, ødemarker. Lige som man tror, at nu skal man se de smukke høje bjerge, kommer tågerne. Der er forståelsesvanskeligheder, bl.a. sproglige og kulturelle (noget pga. arven fra Sovjettiden med beton-bureaukrater $\mathrm{mm}$., andet pga. religion med mænd, der ikke vil trykke én i hånden). Hos kaukaserne møder man en herlig varme og gæstfrihed, og derfor undrer det som sagt, at det er en så konfliktfyldt region.

Men så mindes man om, at Stalin kom fra Gori i Georgien! Og han har spillet en stor rolle for konflikterne i dag, for det var ham, der deporterede tjetjenerne og de meskhetiske tyrkere og andre folkeslag fra Kaukasus. Og det trækker som nævnt stadig spor.

Kaukasus har altid været en smeltedigel: øst og vest - og nord og syd mødes her. Kaukasus har dannet bro mellem Centralasien og Nærorienten. Der er megen kultur, og der er meget varieret kultur. Myterne florerer om det gyldne skind, honning og vin... Noahs ark landede her - på toppen af Ararat, armenernes hellige bjerg (der ligger i Tyrkiet og dermed ikke er tilgængeligt for armenerne, så længe de to lande ikke kan komme overens). Der er fantastiske høje bjerge og smukke, spændende byer. Og så er der gæstfrie og interessante indbyggere, som har tiltrukket besøgende. De store russiske forfattere, Pushkin og Lermontov, var her og skrev. Alexandre Dumas ligeså. Den første kvindelige modtager af Nobels fredspris, Bertha von Suttner, tilbragte sine hvedebrødsdage i Georgien. Også lokale har skrevet - læs Kurban Saids romantiske bog om Ali og Nino (fra hhv. Aserbajdsjan og Georgien).

Kaukasus er ukendt land for de fleste danskere, men sådan har det ikke altid været. Før 1917 spillede danske - og andre skandinaviske erhvervsfolk (bl.a. Nobel) en rolle særligt i Aserbajdsjan. Det var under det første olieboom, og de har efterladt nogle pragthuse i Baku. Rejs til Kaukasus og se selv! Men læs først vores egen Hans Scherfigs poetiske beskrivelser af og tegninger fra en rejse $i$ Georgien i 1968 i Morgenrødens land.

Et lille suk: læsning af bogen var blevet en endnu større nydelse, hvis der var læst ordentlig korrektur på den!

Benedicte Maegaard er fuldmegtig, cand.scient.pol. 